\title{
HUBUNGAN ANTARA HEALTH CONSCIOUSNESS DENGAN EMPLOYEE WELL-BEING PADA KARYAWAN DI DKI JAKARTA
}

\author{
Rizka Amanda dan Nuri Sadida \\ Fakultas Psikologi, Universitas YARSI, Jalan Letjen Suprapto, Jakarta, 10410, Indonesia \\ Email: nuri.sadida@gmail.com
}

\begin{abstract}
ABSTRAK, Kesejahteraan merupakan aspek penting untuk menunjang produktivitas sumber daya manusia. Kesejahteraan di tempat kerja bukan hanya kesejahteraan fisik, namun juga meliputi kesejahteraan psikologis. Kesejahteraan fisik dipengaruhi oleh kesadaran kesehatan dan gaya hidup, sementara kesejahteraan psikologis dipengaruhi oleh beban pekerjaan yang termasuk di dalamnya adalah tenggat waktu, beban kerja, tekanan dari atasan, dan kolega kerja. Penelitian ini bertujuan untuk melihat ada atau tidaknya hubungan antara health consciousness (kesadaran kesehatan) dengan Employee Well-Being (kesejahteraan karyawan) pada karyawan. Penelitian ini menggunakan pendekatan kuantitatif dengan kuesioner sebagai instrumen penelitian. Pada penelitian ini peneliti mengadaptasi alat ukur kesadaran kesehatan yang dibuat oleh Hong pada tahun 2009 dan memodifikasi alat ukur kesejahteraan karyawan yang disusun oleh Juniper pada tahun 2010. Partisipan dalam penelitian ini adalah karyawan kantoran (office) yang bekerja di DKI Jakarta sebanyak 164 partisipan. Data diolah dengan uji Spearman dan didapatkan hasil $r=0,209(\rho=0,007 \leq 0,05)$ yang artinya terdapat hubungan yang positif dan signifikan antara kesadaran kesehatan dengan kesejahteraan karyawan.
\end{abstract}

Kata kunci: Kesadaran Kesehatan, Kesejahteraan Karyawan, Beban Kerja

\begin{abstract}
Well-being is one important thing which support productivity of human resources. Human resources well-being included physical well-being and psychological well-being. Physical well-being is influenced by health consciousness and lifestyle, while psychological well-being is influenced by workload which includes deadlines, workload, pressure from leaders, and colleague support. The purpose of this research is to see the correlation between health consciousness and employee wellbeing of employees. This research use health consciousness measurement scale made by Hong in 2009 and employee well-being measurement scale modified from Junipe's factors that influence employee well being (2010). The partisipants of the research are employees in DKI Jakarta with total 164 partisipants. Result shows there is a positive relationship and significant correlation between health consciousness and employee well-being $r=0,209(\rho=0,007 \leq 0,05$.
\end{abstract}

Key words: Health consciousness;Employee well-being; work load

\section{PENDAHULUAN}

Kesejahteraan merupakan aspek penting untuk menunjang produktivitas sumber daya manusia. Kesejahteraan yang dimaksud bukan hanya kesejahteraan fisik, namun juga meliputi kesejahteraan psikologis. Menurut Vallerand (dalam Anindiati, 2014) ketika kedua aspek kesejahteraan ini terpenuhi, maka karyawan akan menunjukkan produktivitas dan semangat ketika bekerja. Selain itu Harter, Schmid, dan Keyes (dalam Anindiati, 2014) juga mengatakan bahwa karyawan yang memiliki kesejahteraan psikologis yang tinggi akan lebih kooperatif, memiliki tingkat absensi yang rendah, tepat waktu dan efisien, serta dapat bekerja lebih lama pada suatu organisasi

Menurut Juniper (2010) employee well-being (kesejahteraan karyawan) di tempat kerja terpenuhi dengan mengkondisikan berbagai faktor di tempat kerja. Faktorfaktor yang berperan dalam employee well-being menurut Juniper (2010), yaitu advancement, facilities, home work interface, job, physical health, psychological health, dan relationship. Sementara kesejahteraan fisik dipengaruhi oleh faktor-faktor seperti kesadaran akan kesehatan dan gaya hidup. Jayanti dan Burns (dalam Kaynak dan Eksi, 2011) menggambarkan konsep health consciousness (kesadaran kesehatan) sebagai sejauh mana masalah kesehatan yang diintegrasikan ke dalam kegiatan sehari-hari seseorang.
Dampak kurangnya kesadaran menjaga kesehatan dapat menimbulkan penyakit kronis bahkan hingga kerugian bisnis pada perusahaan. Menurut Data Centres for Desease and Prevention di Amerika Serikat pada tahun 2010, terdapat 1,7 juta pekerja usia produktif meninggal setiap tahunnya akibat penyakit kronis seperti jantung, stroke, dan gangguan per-napasan akut. Sementara di Indonesia, hasil survei kesehatan karyawan atau Occupational Health Survelliance Report pada tahun 2012 lalu menyebutkan 30\% karyawan dari 2741 karyawan usia produktif (sebanyak 53\% berusia 31-40 tahun) memiliki risiko tinggi terhadap penyakit jantung, stroke, dan ginjal (Yuliawan, Alamsyah, Adiati, Ashari \& Rusdianto, 2014).

Permasalahan kesadaran kesehatan karyawan pada era modern di kota besar saat ini adalah banyak karyawan yang menyadari pentingnya menjaga kesehatan untuk mendukung performa kerja, akan tetapi mereka mengalami kesulitan menjaga kesehatan dikarenakan memprioritaskan pekerjaan. Hal ini terlihat dari survei yang dilakukan oleh Jakarta Professional Health Index pada tahun 2015 yang melakukan survei tentang kesadaran kesehatan pada karyawan di Jakarta, dan hasilnya menyebutkan bahwa dari 1000 orang karyawan, 96\% di antaranya menyadari kesehatan berpengaruh terhadap kinerja, namun hanya 
$50 \%$ diantaranya yang merealisasikan menjaga kesehatan (Dewi, 2015). Sulitnya menjaga kesehatan menurut survei yang dilakukan oleh Jakarta Professional Health Index tahun 2015 disebabkan oleh karakteristik pekerjaan seperti tenggat, beban kerja, tekanan dari atasan, dan kolega kerja. Karyawan yang mampu menjaga kesehatan dapat dipengaruhi oleh karakteristik pekerjaan yang mendukung, seperti jam kerja yang fleksibel. Hal ini disimpulkan dari penelitian Moen, Kelly, Tranby, dan Huang (2011), yang mengungkapkan karyawan yang memiliki waktu kerja lebih fleksibel memiliki perilaku sehat yang tinggi.

Tidak hanya pada mempengaruhi kesejahteraan fisik, dampak negatif dari pola hidup kurang sehat juga mempengaruhi produktivitas kerja dan kesejahteraan psikologis karyawan di tempat kerja. Menurut survei yang dilakukan oleh Professional Health Index tahun 2015, akibat dari kurangnya hidup sehat, terlihat bahwa di tempat kerja karyawan mengalami pegal-pegal dan rasa mudah lelah (Pradesha, 2015). Berdasarkan hasil survei yang dilakukan oleh jobstreet.com pada September 2014 menunjukkan hasil bahwa $62 \%$ karyawan di Jakarta mengalami kesulitan untuk tidur nyenyak karena masih memikirkan pekerjaan. Sebanyak 38\% lainnya memikirkan pekerjaan kantor mereka saat perjalanan pulang kerja (Iswahyudi, 2015).

\section{Health Consciousness}

Kraft \& Goodell (dalam Hong, 2009) mengatakan bahwa kesadaran kesehatan berorientasi pada gaya hidup sehat. Pendapat lainnya diungkapkan oleh Gould (dalam Hong, 2009) yang mengatakan bahwa kesadaran kesehatan dianggap semata-mata sebagai status psikologis atau batin seseorang, termasuk kewaspadaan kesehatan, kesadaran diri kesehatan, keterlibatan kesehatan, dan selfmonitoring kesehatan seseorang. Jadi, dapat disimpulkan bahwa kesadaran kesehatan adalah penilaian individu atas kesehatannya serta keterlibatan individu dalam menjaga kesehatannya, seperti menjalankan gaya hidup sehat dan mencari dan menggunakan informasi tentang kesehatan.

Hong (2009) mengonsep ulang dimensi yang telah dibuat oleh peneliti sebelumnya dan menemukan tiga dimensi dalam health consciousness, yaitu: (1) Self-health awareness, kecenderungan untuk memfokuskan perhatian pada perilaku sehat seperti aktivitas, ketertarikan, dan pendapat yang berorientasi pada kesehatan; (2) Personal responsibility, orang yang sadar akan kesehatan merasa lebih bertanggung jawab untuk menjaga kesehatan dan cenderung tidak hanya terlibat dalam perilaku pencegahan dan menjaga kesehatan di kehidupan sehari-hari, tetapi juga secara aktif berpartisipasi dalam komunitas kesehatan; (3) Health motivation, indikator motivasi intrinsik individu untuk menjaga kesehatan yang baik serta refleksinya atau tanggung jawabnya terhadap kesehatan.

\section{Employee Well-Being}

Untuk definisi yang berhubungan dengan pekerjaan tertentu, EWB dipandang sebagai istilah lain untuk kepuasan kerja. Sheppard (dalam Juniper, 2010), misalnya, menunjukkan bahwa kepuasan kerja subjektif merupakan pusat EWB. Sementara itu menurut Danna dan Griffin (dalam Juniper, 2010) EWB tidak semata-mata hanya kepuasan kerja belaka. Danna dan Griffin (dalam Juniper, 2010) mengatakan bahwa EWB adalah perpaduan menyeluruh kesehatan dan kesejahteraan di tempat kerja. Juniper (2010) mengatakan bahwa terdapat kesepakatan umum bahwa EWB adalah dinamis, subjektif, dan berbeda secara konseptual dengan kepuasan kerja, serta mengacu pada keadaan psikologis.

Jadi, berdasarkan definisi-definisi dari EWB yang telah dipaparkan sebelumnya dapat disimpulkan bahwa EWB adalah deskripsi personal pekerja tentang seberapa positif dan seimbang keadaan dirinya di lingkungan kerja yang dipengaruhi dan diintervensi oleh faktor dari lingkungan kerja. Dalam tesisnya, Juniper (2010) menyebutkan bahwa terdapat tujuh domain atau wilayah dalam EWB, antara lain: (1) Advancement (ADV) menjelaskan deskripsi personal karyawan terhadap kebutuhan pelatihan dan promosi pada karyawan yang berkontribusi pada kesejahteraan karyawan; (2) Facilities (FAC) menjelaskan deskripsi personal karyawan terhadap kebutuhan karyawan dalam lingkungan kerja seperti akomodasi dan fasilitas di tempat kerja yang berkontribusi pada kesejahteraan karyawan; (3) Home Work Interface (HWI) menjelaskan deskripsi personal pekerja terhadap pekerjaan yang karyawan jalani berdampak tanggung jawab karyawan di luar pekerjaan serta bagaimana pekerjaan yang karyawan jalani berkontribusi pada kehidupan pribadi karyawan; (4) Job (JOB) menjelaskan deskripsi personal karyawan terhadap aspek tertentu atau unsur intrinsik dalam pekerjaan yang berkontribusi pada kesejahteraan karyawan; (5) Physical Health (PHY) menjelaskan deskripsi personal karyawan terhadap bagaimana pekerjaan yang karyawan jalani berkontribusi pada kesehatan fisik karyawan; (6) Psychological Health (PSY) menjelaskan deskripsi personal karyawan terhadap bagaimana pekerjaan karyawan berkontribusi pada kondisi kesehatan psikologis karyawan yang kemudian berkontribusi pada kesejahteraan karyawan; (7) Relationship (REL) menjelaskan deskripsi personal terhadap bagaimana hubungan karyawan dengan pimpinan serta koleganya yang berkontribusi pada kesejahteraan karyawan. Berdasarkan paparan tersebut maka peneliti ingin mengetahui ada atau tidaknya hubungan antara health consciousness dengan employee well-being pada karyawan di DKI Jakarta.

\section{METODE}

Penelitian ini menggunakan pendekatan penelitian kuantitatif dengan jenis rancangan penelitian yakni korelasi, dengan variabel pertama yaitu health consciousness dan variabel kedua yaitu employee well-being. 
Terdapat hubungan antara health consciousness dengan employee well-being pada karyawan.

Pada penelitian ini populasi yang digunakan adalah karyawan yang bekerja di DKI Jakarta. Alasan digunakannya DKI Jakarta sebagai populasi dalam penelitian ini dikarenakan berdasarkan survei, disebutkan hanya 50\% dari 1000 karyawan yang menjaga kesehatannya (Dewi, 2015). Selain itu, berbagai survei menyebutkan bahwa karyawan mengalami rendahnya gejala well-being, seperti mudah lelah (Pradesha, 2015), tidak bahagia dengan pekerjaannya (Triananda, 2014), tidak bisa tidur karena memikirkan pekerjaan, dan terjadi lompatan stres kerja selama tiga tahun belakangan (Pininta, 2016). Hal ini menunjukkan terdapat fenomena karyawan dengan tingkat kesadaran kesehatan dan kesejahteraan karyawan yang rendah.

Sampel yang digunakan dalam penelitian ini adalah karyawan berjumlah 164 orang dengan karyawan lakilaki adalah 93 orang dan karyawan perempuan adalah 66 orang. Partisipan direkrut menggunakan teknik accidental sampling. Kriteria partisipan adalah karyawan yang bekerja di DKI Jakarta.

Penelitian ini menggunakan kuesioner sebagai instrumen penelitian yang terdiri dari dua alat ukur. Alat ukur yang pertama adalah health consciousness yang peneliti gunakan dengan mengadaptasi alat ukur health consciousness yang dibuat oleh Hong (2009), yang mengukur tiga dimensi, yaitu self-health awareness, personal responsibility, dan health motivation. Alat ukur selanjutnya adalah employee well-being, peneliti memodifikasi alat ukur employee well-being yang telah dibuat oleh Juniper (2010).

Langkah adaptasi yang dilakukan adalah pertama kali menerjemahkan aitem ke dalam Bahasa Indonesia, lalu diterjemahkan kembali (back-translate) ke penerjemah tersumpah. Setelah itu peneliti berdiskusi dengan dua orang ahli (expert judgement), yang di-lanjutkan dengan uji keterbacaan pada beberapa orang untuk memastikan bunyi aitem mudah dipahami.

\section{Health Consciousness}

Skala health consciousness disusun menggunakan 7 pilihan jawaban skala likert di antaranya, $1=$ Sangat Tidak Setuju, 2 = Tidak Setuju, $3=$ Agak Setuju, $4=$ Netral, $5=$ Agak Setuju, $6=$ Setuju, dan $7=$ Sangat Setuju. Alat ukur ini terdiri dari 11 aitem dengan 10 aitem favorable dan 1 aitem unfavorable.

Dalam melakukan uji coba alat ukur peneliti menggunakan uji coba alat ukur terpakai, yaitu data yang digunakan untuk menguji validitas dan reliabitas instrumen juga digunakan sebagai data akhir penelitian. Pada hasil uji coba terpakai menunjukkan koefisiensi reliabilitas Cronbach's Alpha $>0.8$ yang berarti alat ukur ini dapat dinilai reliabel.
Sedangkan untuk uji validitas menggunakan korelasi bivariate pearson, terdapat satu aitem yang gugur. Aitem ini gugur dikarenakan skor corrected item total di bawah 0.2. Setelah itu, dilakukan penghitungan ulang dengan menggunakan 10 aitem yang kemudian menunjukkan nilai corrected item total $>0,2$ yang berarti aitem dalam alat ukur ini dapat dikatakan valid.

\section{Employee Well-Being}

Dalam alat ukur ini dimensi yang dibuat oleh Juniper (2010) terdiri dari 7 dimensi, antara lain advancement, facilities, home work interface, job, physical health, psychological health, dan relationship. Alat ukur ini disusun menggunakan skala likert dengan lima pilihan jawaban, Sangat Setuju (SS), Setuju (S), Netral (N), Tidak Setuju (TS), dan Sangat Tidak Setuju (STS). Alat ukur ini terdiri dari 40 aitem dengan 22 aitem favorable dan 18 aitem unfavorable.

Dalam melakukan uji coba alat ukur peneliti menggunakan uji coba alat ukur terpakai. Pada hasil uji coba terpakai menunjukkan koefisiensi reliabilitas Cronbach's Alpha $>0.8$ yang berarti bahwa alat ukur ini dapat dinilai reliabel. Sedangkan untuk uji validitas terdapat dua aitem yang gugur. Kemudian dilakukan penghitungan ulang dengan menggunakan 38 aitem yang kemudian menunjukkan nilai corrected item total $>0.2$ yang artinya aitem dalam alat ukur ini dapat dikatakan valid.

\section{Uji Statistik}

Dalam penelitian ini peneliti menggunakan 3 jenis uji statistik yakni, uji normalitas, uji korelasi, dan uji demografis. Uji normalitas pada penelitian ini menggunakan Kolmogorov - Smirnov dimana data dapat dikatakan normal apabila tingkat signifikansi di atas $\alpha=0,05(\rho>0,05)$ (Pramesti, 2016).

Hasil dari uji normalitas menentukan teknik uji korelasi yang digunakan. Apabila data terdistribusi normal, maka uji korelasi akan menggunakan teknik parametrik, misalnya uji dengan korelasi Pearson. Sedangkan apabila data terdistribusi tidak normal, uji korelasi akan menggunakan teknik non parametrik, seperti misalnya uji Spearman (Setiaman, 2018). Karena pada hasil uji normalitas menunjukkan bahwa salah satu variabel yakni health consciousness berdistribusi tidak normal, dimana $\rho=0,006(\rho<0,05)$ maka peneliti menggunakan metode statistik non-parametrik. Teknik analisis yang digunakan adalah korelasi Spearman untuk menguji korelasi antar kedua variable penelitian. Teknik analisis korelasi Spearman data dinilai memiliki hubungan apabila nilai signifikansi alpha kurang dari 0,05 $(\rho \leq 0,05)$. Analisa uji beda variabel demografis untuk data yang terdistribusi tidak normal menggunakan analisa Mann Whitney dan Kruskal Wallis (Sugiyono, 2013). 


\section{HASIL DAN PEMBAHASAN}

Partisipan yang berpartisipasi dalam penelitian ini berjumlah 164 orang karyawan, dengan gambaran demografis dijelaskan pada Tabel 1.

Tabel 1. Data Demografi Partisipan

\begin{tabular}{lll}
\hline \multicolumn{1}{c}{ Variabel } & \multicolumn{1}{c}{ Jumlah } & Persentase \\
\hline JENIS KELAMIN & & \\
Laki-laki & 98 & $60 \%$ \\
Perempuan & 66 & $40 \%$ \\
RENTANG USIA & & \\
$<45$ tahun & 159 & $96 \%$ \\
$>45$ tahun & 5 & $4 \%$ \\
STATUS PERNIKA- & & \\
HAN & & $51 \%$ \\
Menikah & 84 & $49 \%$ \\
BelumMenikah & 80 & \\
LEVEL JABATAN & & $75 \%$ \\
Staff & 123 & $8 \%$ \\
Admin & 13 & $3 \%$ \\
Manager & 5 & $14 \%$ \\
Supervisor & 23 & \\
MASA KERJA DI & & \\
TEMPAT KERJA & & $63 \%$ \\
SAAT INI & & $37 \%$ \\
$<5$ tahun & 104 & \\
$>5$ tahun & 60 & \\
PENDIDIKAN & & \\
TERAKHIR & & \\
SMA & 15 & \\
D3 & 58 & \\
S1 & 82 & \\
S2 & 9 & \\
\hline
\end{tabular}

Data demografi di atas yang sudah memiliki kategori yang jelas adalah jenis kelamin, status pernikahan, level jabatan, dan pendidikan terakhir. Sementara untuk rentang usia, kategori dibagi berdasarkan tingkat kematangan karir Super (1980) yang menyatakan bahwa usia 45 tahun adalah batas waktu dimana seseorang memperoleh posisi bagus dan aman di tempat kerja. Sementara batas pengalaman kerja lima tahun berdasarkan teori Buchanan (1974) yang menyatakan bahwa selama lima tahun pertama bekerja adalah masa awal karir yang menentukan komitmen seseorang di tempat kerja.

\section{Uji Korelasi}

Berdasarkan uji korelasi didapatkan bahwa hubungan antara health consciousness dan employee well-being menghasilkan nilai rs $=0,209(\rho=0,007 \leq 0,05)$. Dengan hasil koefisien tersebut maka dapat disimpulkan bahwa semakin tinggi health consciousness yang dimiliki seorang karyawan, maka semakin tinggi pula employee well-being yang dimiliki karyawan tersebut. Berdasarkan kategori kekuatan hubungan korelasi hasil dari uji korelasi penelitian ini termasuk dalam korelasi yang rendah.
Dari hasil tersebut dapat diartikan bahwa ketika karyawan merasa kesadaran kesehatannya tinggi, maka kesejahteraannya sebagai karyawan pun juga akan tinggi. Hasil dalam penelitian ini sejalan dengan penelitian yang dilakukan oleh Hassen dan Kibret (2016), dimana dalam penelitian tersebut ditemukan bahwa terdapat hubungan yang positif antara kesadaran kesehatan dengan kesejahteraan psikologis.

Menurut Hassen dan Kibret (2016) kesadaran kesehatan merupakan kesadaran individu dari usaha meningkatkan kesehatan dan pemahaman bahwa kesehatan seseorang tergantung pada sejauh mana seorang individu mengurus dirinya. Hassen dan Kibret (2016) juga mengatakan bahwa sekitar 70-80\% fungsi potensial seseorang dalam menjaga kesehatan ditentukan oleh bagaimana individu tersebut memilih gaya hidup dalam hidupnya yang mana perilaku ini dapat berhubungan positif maupun negatif pada kesadaran kesehatan dan kesejahteraan psikologis seseorang. Dengan begitu dapat diasumsikan bahwa ketika seseorang memiliki kesadaran kesehatan yang tinggi maka hal tersebut dapat berhubungan positif maupun negatif bagi kesejahteraan psikologis seseorang, termasuk kesejahteraan psikologis di tempat kerja.

Berdasarkan kekuatan hubungan hasil dari penelitian ini menunjukkan bahwa kesadaran kesehatan dan kesejahteraan karyawan memiliki kekuatan hubungan yang rendah, yang terlihat dari koefisien korelasi yang dibuat kuadrat dan menghasilkan $\mathrm{R} 2=0.043$. Angka tersebut mengindikasikan lemahnya hubungan, yaitu $4.3 \%$ peran dari kesadaran kesehatan terhadap employee well-being. Peneliti menduga bahwa terdapat faktor lain yang menyumbangkan kontribusi terhadap kesejahteraan karyawan yang lebih besar. Faktor yang diduga memiliki kontribusi besar itu adalah lingkungan sosial dalam pekerjaan. Kesimpulan ini diambil dari penelitian Daniels, Watson, Gedikli (2017) yang menyarikan model employer-employee relations dan menerangkan bahwa faktor-faktor lingkungan sosial pekerjaan seperti persepsi akan dukungan organisasi, iklim organisasi, identitas sosial, dan keadilan sosial di tempat kerja adalah faktor-faktor yang menentukan well-being karyawan. Sedangkan menurut De Jonge, dkk (2001), terdapat tiga karakteristik jabatan yang mempengaruhi EWB karyawan, yaitu tuntutan pekerjaan, otonomi pekerjaan, dan dukungan sosial dari tempat kerja.

\section{Uji Beda Faktor Demografis}

Selain melakukan uji korelasi untuk menjawab pertanyaan utama penelitian, peneliti juga melakukan uji beda variabel EWB. Dari hasil uji beda, ditemukan bahwa hanya variable demografis pendidikan terakhir yang memiliki perbedaan employee well-being yang signifikan antar kelompok dengan nilai $\rho=0.011 \leq 0.05$. 
Tabel 2. Rata-rata skor EWB berdasarkan tingkat pendidikan

\begin{tabular}{lcc}
\hline \multicolumn{1}{c}{ Kelompok } & N & Mean Rank \\
\hline SMA/SMK & 15 & 82,77 \\
D3 & 58 & 85,39 \\
S1 & 82 & 80,99 \\
S2 & 9 & 77,22 \\
\hline
\end{tabular}

Perbedaan rata-rata skor EWB karyawan berdasarkan tingkat pendidikan akhirnya ditampilkan dalam Tabel 2. Dari tabel tersebut dapat dilihat bahwa kelompok D3 memiliki nilai mean yang tinggi, yakni 85,39 sementara kelompok S2 memiliki nilai mean yang rendah dengan nilai 77,22.

Dari hasil uji beda ditemukan bahwa kelompok karyawan dengan pendidikan terakhir S2 memiliki EWB paling rendah. Hasil ini sejalan dengan penelitian SousaPoza dan Sousa-Poza (2000) yang menyatakan bahwa tingginya tingkat pendidikan seseorang berkorelasi terbaik dengan kepuasan kerja, dimana kepuasan kerja adalah indikator dari EWB. Menurut Clark dan Oswald (1996), semakin tinggi pendidikan seseorang, maka semakin tinggi ekspektasi seseorang akan hasil yang dapat mereka raih, sehingga mereka menjadi kesulitan merasakan kepuasan atau kesejahteraan di tempat kerja.

Keterbatasan penelitian ini adalah peneliti tidak menganalisa lebih lanjut dimensi-dimensi apa saja yang dapat mempengaruhi kesadaran kesehatan dan kesejahteraan pada karyawan, seperti persepsi akan dukungan organisasi, iklim organisasi, identitas sosial, karakteristik jabatan seperti tuntutan pekerjaan dan otonomi pekerjaan. Selain itu, masih minimnya literatur yang membahas tentang kesadaran kesehatan di tempat kerja, lebih khususnya kesadaran kesehatan dengan EWB secara global maupun di Indonesia. Hal tersebut membuat minimnya penjelasan untuk hubungan kedua variabel ini. Sebelumnya terdapat penelitian yang dilakukan oleh Kuoppala (2008) yang menjelaskan terdapat pengaruh dari bentuk tertentu promosi kesehatan dengan EWB. Namun belum dapat disimpulkan apakah pengaruh bentuk promosi kesehatan terhadap EWB dimediasi oleh kesadaran kesehatan atau bukan.

\section{SIMPULAN}

Hasil uji korelasi menunjukkan bahwa terdapat hubungan yang positif antara health consciousness dengan employee wellbeing pada karyawan di DKI Jakarta. Dengan kata lain semakin tinggi nilai kesadaran kesehatan seseorang maka semakin tinggi pula nilai kesejahteraannya. Hasil analisis tambahan yang dilakukan pada kesejahteraan karyawan menunjukkan bahwa terdapat perbedaan signifikan pada kelompok pendidikan terkahir. Untuk penelitian selanjutnya disarankan untuk menggunakan subjek atau partisipan penelitian di berbagai macam bidang industri agar dapat melihat hubungan antara kesadaran kesehatan dan kesejahteraan karyawan pada berbagai macam bidang industri.

Untuk penelitian mendatang, agar meneliti faktor persepsi akan dukungan organisasi, iklim organisasi, identitas sosial, karakteristik jabatan seperti tuntutan pekerjaan dan otonomi pekerjaan. Kemudian apabila penelitian mendatangkan menggunakan skala dalam penelitian ini, diharapkan dapat menguji kualitas psikometrik dari alat ini dengan cara memvalidasi alat ukur EWB dengan berbagai indikator EWB seperti, burnout, kepuasan kerja, dan stres kerja. Hal ini dikarenakan alat ukur EWB dalam penelitian ini belum banyak digunakan dalam konteks pekerjaan di Indonesia, sehingga belum banyak data untuk menyimpulkan kualitas psikometrik alat ini. Selain itu, untuk membuktikan dugaan faktor lain yang dianggap memiliki peran yang lebih besar terhadap EWB karyawan Jakarta, maka perlu diadakan penelitian terkait variabel.

Hasil dari penelitian ini juga diharapkan akan memberikan manfaat kepada karyawan pentingnya men-jaga kesehatan untuk menunjang kesejahteraan mereka secara keseluruhan di tempat kerja. Selain itu manfaat untuk perusahaan diantaranya menguatkan pentingnya perusahaan melakukan promosi kesehatan kepada karyawan yang diharapkan dapat meningkatkan kesadaran kesehatan karyawan, yang pada akhirnya dapat menunjang EWB karyawan.

\section{DAFTAR PUSTAKA}

Anindiati, Q. (2014). Hubungan Konflik Individu dalam Organisasi dengan Kesejahteraan Psikologi Karyawan di Tempat Kerja. Skripsi. Sumatera Utara, Sumatera, Indonesia : Fakultas Psikologi, Universitas Sumater Utara

Buchanan, B. (1974). Building organizational commitment: The socialization of managers in work organizations. Administrative science quarterly, 533-546.

Clark, A.E., Oswald, A.J., 1996. Satisfaction and comparison income. Journal of Public Economics 61, 359-381.

Daniels, K., Watson, D., \& Gedikli, C. (2017). Well-being and the social environment of work: A systematic review of intervention studies. International journal of environmental research and public health, 14(8), 918.

De Jonge, J., Dormann, C., Janssen, P. P., Dollard, M. F., Landeweerd, J. A., \& Nijhuis, F. J. (2001). Testing reciprocal relationships between job characteristics and psychological well-being: A cross-lagged structural equation model. Journal of occupational and organizational psychology, 74(1), 29-46 
Dewi, S. W. (2015, May 20). Half of Jakarta Professionals Yet To Live Healthy: Survei. Diambil dari The JakartaPost: http://www.thejakartapost.com/ news/2015/05/20/half-jakarta-professionals-yet-livehealthy-survei.html

Hassen,A., \& Kibret, B. T. (2016). Health-Related Behaviors, Health Consciousness and Psychological Wellbeing among Teaching Faculty in Jimma University, Ethiopia. Clinical and Experimental Psychology, Vol. 2, 113-121.

Hong, H. (2009). Scale Development for Measuring Health Consciousness: Re-Conceptualization. Columbia, Missouri, United States: 12th Annual International Public Relations Research Conference, Holiday Inn University of Miami Coral Gables, Florida.

Iswahyudi,S.(2015,Mei27). Kerja di Jakarta Ternyata Enggak Bikin Tidur Nyenyak? Diambil dari Careernews:http://careernews.id/youknow/ view/3313-Kerja-di-Jakarta-Ternyata-EnggakBikin-Tidur-Nyenyak

Jindabot, T. (2015). The Relationship of Thai Consumers' Health Consciousness and Perceived Value. Proceeding of the Second Middle East Conference on Global Business, Economics, Finance, and Banking, Vol. 252, 1-10.

Juniper, B. (2010). Evaluation of A Novel Approach To Measuring Well-Being in Work Place. Thesis. Cranfield, England: Cranfield University.

Kaynak, R., \& Eksi, S. (2011). Ethnocentrism, Religiosity, Envionmental, and Health consciousness: Motivators for Anti Consumers. Eurasian Journal ofBusiness and Economics, Vol. 4, No: 8, 31-50.

Kuoppala, J., Lamminpää, A., \& Husman, P. (2008). Work health promotion, job well-being, and sickness absences - a systematic review and meta-analysis. Journal of occupational and environmental medicine, 50(11), 1216-1227.

Nurkaukab. (2004, November 01). Berpuasalah, Maka Akan Sehat. Diambil dari Suara Merdeka: http://www. suaramerdeka.com/harian/0411/01/ragam04.htm

Pininta, A. (2016). Tiga dari Empat Karyawan Susah Tidur Karena Pikirkan Pekerjaan di Kantor. Diambil dari http://palembang.tribunnews.com/2016/03/15/tigadari-empat-karyawan-susah-tidur-karena-pikirkanpekerjaan-di-kantor

Pradesha, N. T. (2015, May 19). Hasil Survei: Warga Jakarta Kebanyakan Kerja, Kurang Olahraga. Diambil dari
CNN Indonesia: http://www.cnnindonesia.com/ gaya-hidup/20150519174526-255-54296/hasilsurvei-warga-jakarta-kebanyakan-kerja-kurangolahraga/

Purwana, A. E. (2014). Kesejahteraan Dalam Perspektif Ekonomi Islam. Skripsi. Ponorogo, Jawa Timur: Fakultas Syari'ah dan Ekonomi, Universitas STAIN.

Rukoyah, Y., Khofifah, N., Diana, S., \& Pujiati. (2014). Konsep Sehat dan Sakit dalam Islam. Malang, Jawa Timur, Indonesia: Universitas Islam Negeri.

Setiaman, S. (2018). Praktikum Analisa Data Kuantitatif Dengan SPSS. Diambil dari https://www.academia. edu/37921088/Analisis_Data_Kuantitatif_Dengan_ SPSS

Sousa-Poza, A., \& Sousa-Poza, A. A. (2000). Well-being at work: a cross-national analysis of the levels and determinants of job satisfaction. The journal of socioeconomics, 29(6), 517-538.

Super, D. E. 1980. “A Life-span, Life-space Approach to Career Development." Journal of Vocational Behavior 16:282-298

Tahrir, H. (2011, Juli 14). Kesejahteraan dalam Islam. Diambil dari Al-Wa'ie: http:/hizbut- tahrir. or.id/2011/07/14/kesejahteraan-dalam-islam/

Triananda, K. (2014). Survei: Dari 30 Negara, Karyawan di Indonesia Paling Tidak Bahagia. Diambil dari https://www.beritasatu.com/ekonomi/182879survei-dari-30-negara-karyawan-di-indonesiapaling-tidak-bahagia.html

Tuasikal, M. A. (2009, November 09). Nikmat Sehat Waktu Luang Yang Membuat Manusia Tertipu. Diambil dari Rumaysho.com: https://rumaysho.com/634-nikmatsehat-dan-waktu-luang-yang-membuat-manusiatertipu.html

Moen, P., Kelly, E., Tranby, E., \& Huang, Q. (2011). Changing Work, Changing Health: Can Real WorkTime Flexiblity Promote Health Behaviors and WellBeing? Journalof Health and Social Behavior, Vol. 52, 404-429.

Wakhidah, N. (2015). Psychological Well-Being Pada Caregiver Penyakit Terminal di Kota Malang. Skripsi. Malang, Jawa Timur, Indonesia: Fakultas Psikologi, Universitas Islam Negeri.

Yuliawan, R. H., Alamsyah, N. D., Adiati, N., Ashari, M., \& Rusdianto, E. (2014, February). Karyawan Sehat, Karyawan Produktif. InternalMagazine. Sulawesi Selatan,Sulawesi, Indonesia: PT. Vale Indonesia Tbk. 